\title{
EVALUASI TIM PENEGASAN BATAS DAERAH (Studi Kasus di Provinsi Lampung dan Kalimantan Timur)
}

\author{
The Evaluation of Region Emphasis Team \\ (Case Study in Lampung Province and East Kalimantan Province)
}

\author{
1) Djoko Sulistyono, 2) Deden Nuryadin, dan 3) Anung S. Hadi \\ Pusat Penelitian Pemerintahan Umum dan Kependudukan \\ Badan Penelitian dan Pengembangan Kementerian Dalam Negeri \\ Jl. Kramat Raya No. 132 Jakarta Pusat \\ E-mail: djoksul2013@gmail.com
}

Dikirim: 5 Januari 2014; direvisi: 13 Januari 2014; disetujui: 12 Februari 2014

\begin{abstract}
Abstrak
Penelitian ini akan melihat masalah tapal batas yang sering menjadi persoalan pelik. Sejak dibukanya "kran" pemekaran daerah, hingga saat ini tercatat ada sebanyak 946 konflik sengketa perbatasan, baik antarkabupaten/kota dalam satu provinsi, maupun kabupaten/kota dalam satu provinsi dengan kabupaten/kota di provinsi tetangga. Penelitian ini melihat lebih khusus tentang evaluasi Tim Penegasan Batas Daerah yang merupakan salah satu bagian dalam rangka percepatan penegasan batas daerah. Metode deskriptif kualitatif yang digunakan, melalui teknik wawancara mendalam dengan memakai pendekatan kualitatif sebagai konsentrasi utama pada penelitian ini. Lokasi penelitian secara kasus akan melihat di Provinsi Lampung dan Kalimantan Timur. Provinsi Lampung dipilih karena merupakan salah satu provinsi di Indonesia yang rawan konflik batas daerah, sedangkan Kalimantan Timur dipilih karena provinsi ini kaya sumber daya alam (SDA). Masalah umum yang dihadapi di kedua provinsi ini antara lain: adanya keterbatasan sumber daya manusia yang profesional (tenaga ahli segmen batas), kurangnya koordinasi antara pemerintah-pemerintah daerah yang berbatasan, sarana dan prasarana yang belum menjangkau sampai ke daerah pelosok, serta kurangnya dukungan pimpinan di dalam program kerja Penegasan Batas Daerah, yang dianggap belum menjadi hal yang prioritas.

Kata kunci: evaluasi, tim penegasan batas daerah
\end{abstract}

\begin{abstract}
This study examines the matter of boundary that often a thorny issue. Since opening of the "faucet" regional expansion, until now, there were as many as 946 border dispute conflict, both between districts/cities in the province, and district/city in the province of the district/city in the neighboring province. This study examines only the boundary assertion evaluation team, which is one part the acceleration of boundary assertion. Qualitative descriptive methods were used, through in-depth interview techniques with qualitative and quantitative approaches, as well as a major consentration on the qualitative approach. Location research purposively determined in Lampung and East Kalimantan. Lampung chosen because it is one of the provinces in Indonesia which limits conflict-prone regions, while the East Kalimantan province was chosen because it is rich in natural resources. A common problem encountered in the these two provinces, among others: the limited human resources professional (expert segment boundary), the lack of coordination between governments adjacent areas, facilities and infrastructure that have not reached into rural areas, as well as a lack of leadership support in the work program which is considered the limit assertion has not become a priority.

Keywords: evaluation, region emphasis team
\end{abstract}

\section{PENDAHULUAN}

Tulisan ini bertujuan mengevaluasi kinerja tim penegas batas daerah serta memberikan rekomendasi kebijakan maupun teknis untuk mengefektifkan penegasan batas daerah. Seperti diketahui, Peraturan Menteri Dalam Negeri Nomor 76 Tahun 2012 tentang Pedoman Penegasan Batas Daerah (menggantikan Peraturan Menteri Dalam Negeri Nomor 1 Tahun 2006) menyatakan, bahwa penentuan batas daerah secara pasti, sangat diperlukan untuk melaksanakan amanat undang-undang tentang pembentukan daerah dan dalam rangka menciptakan kepastian hukum wilayah administrasi pemerintahan. Pelaksanaan penentuan batas daerah secara pasti tersebut dilakukan secara sistematis dan terkoordinasi. ${ }^{1}$ Dalam rangka penentuan batas daerah tersebut, maka dibentuk Tim Penegas Batas Daerah, di tingkat pusat, provinsi dan kabupaten/kota, berdasarkan Peraturan Menteri Dalam Negeri dimaksud. ${ }^{2}$

Mengkaji tentang wilayah, maka wilayah negara, baik berupa darat, laut dan ruang di atasnya, adalah merupakan salah satu unsur utama dari suatu

\footnotetext{
1 Bagian "Menimbang" huruf a. dan b. Permedagri No. 76 Tahun 2012.

2 Pasal 18-20 Permendagri No. 76 Tahun 2012 (pasal 18 Permendagri No. 1 Tahun 2006).
}

Evaluasi Tim Penegasan Batas Daerah (Studi Kasus di Provinsi Lampung dan Provinsi Kalimantan Timur) Djoko Sulisttyono, Deden Nuryadin, dan Anung S. Hadi | 53 
negara. Wilayah itu merupakan satu kesatuan dan sebagai tempat untuk bekerjanya suatu unsur negara yang lain, yaitu penyelenggara pemerintahan negara dan rakyatnya. Dengan demikian, wilayah negara itu merupakan wilayah kekuasaan atau wewenang dari negara (state domain).

Di dalam wilayah negara itu, terdapat adanya suatu pemisahan antara daerah satu dengan daerah lainnya yang disebut batas antardaerah. Dalam ruang lingkup batas daerah inilah dilaksanakan penyelenggaraan kewenangan masing-masing daerah. Dalam arti, kewenangan pada suatu daerah pada dasarnya tidak boleh diselenggarakan melampaui batas daerah yang lain dan telah ditetapkan dalam peraturan perundang-undangan.

Adanya kejelasan dan kepastian hukum terhadap batas wilayah di suatu daerah dari hasil penegasan batas yang ditetapkan Menteri Dalam Negeri dengan produk Peraturan Menteri Dalam Negeri. Hal inilah yang kemudian harus dimuat di dalam suatu peta sebagai suatu titik koordinat batas daerah. Penuangan di dalam suatu Peta batas daerah kemudian dilanjutkan sebagai titik koordinat yang tercantum dalam lampiran suatu undang-undang.

Penentuan titik koordinat merupakan salah satu syarat penentuan segmen batas daerah yang mencakup batas wilayah darat dan laut serta batas antarnegara. Penentuan segmen batas ini dan jika sudah disetujui oleh kedua belah pihak atau lebih, dan sudah dikeluarkan suatu regulasi oleh Menteri Dalam Negeri haruslah dianggap sudah final dan berketetapan hukum yang pasti. Jika masalah tersebut tidak diselesaikan secara prosedur-prosedur yang sudah ditentukan, dikhawatirkan berpotensi untuk terjadinya suatu konflik tapal batas.

Selain itu, akibat berlarutnya penentuan batas wilayah, menyebabkan masyarakat di perbatasan tidak terurus dengan baik. Sehubungan dengan itu, Menteri Dalam Negeri meminta gubernur untuk mempercepat penyelesaian masalah batas antardaerah. Hal ini dikarenakan dampak sengketa batas daerah bukan saja menghambat penyelenggaraan pemerintahan dan pemanfaatan sumber daya alam, melainkan juga menimbulkan konflik sosial di daerah perbatasan (Gamawan Fauzi, Menteri Dalam Negeri, dikutip Henricus dalam catatan.co.id pada 26 April 2012).

Penyelesaian tapal batas ataupun segmen batas daerah selama ini memang masuk dalam kewenangan Pemerintah. Akan sangat beralasan jika Pemerintah dengan azas dekonsentrasi dan tugas pembantuan, membentuk Tim Penegas Batas Daerah Provinsi dan Tim Penegas Batas Daerah Kabupaten/Kota.

Oleh karena wewenang tersebut merupakan wewenang Pemerintah Pusat, maka implikasinya adalah Pemerintah Pusat memberikan pendanaan kepada pihak-pihak yang menerima wewenang dekonsentrasi dan tugas pembantuan tersebut. Di samping itu, Pemerintah Pusat juga seharusnya memberikan perbantuan tenaga ahli dan peralatan yang memadai kepada provinsi dan kabupaten/kota sehingga tujuan untuk mempercepat penegasan batas daerah secara efektif, efisien dan dapat diterima para pihak, dapat tercapai.

Jika melihat kondisi alam yang begitu sulit untuk ditelusuri segmen batasnya, maka pemasangan patok batas yang ada kadang masih mengacu pada batas alam sehingga belum memenuhi standar yang ada. Kendati demikian, komitmen Pemerintah Pusat dalam menyelesaikan batas daerah sudah terlihat antara lain dengan memberikan bantuan untuk penyusunan segmen dan pilar koordinat batas daerah (M. Guntur, Kepala Biro Tata Pemerintahan Sekretariat Daerah Provinsi Riau, dalam goriau.com pada 22 September 2012).

Cukup banyak ekses yang mungkin timbul bila batas-batas antardaerah ini belum diselesaikan. Masalah batas daerah tak menutup kemungkinan akan memicu konflik di daerah. Setidaknya ada empat faktor penyebab munculnya konflik di perbatasan daerah, yakni: a) Ketidakjelasan undang-undang pembentukan suatu daerah otonom; b) Adanya perebutan sumberdaya alam; c) Faktor kesukuan, kultur dan etnis; d) Proses penyelesaian sengketa batas daerah selama ini terkesan lamban, dan di sisi lain memerlukan banyak tahapan dalam mekanisme penyelesaiannya (Eko Subowo, Direktur Wilayah Administrasi dan Perbatasan, Direktorat Jendral Pemerintahan Umum Kemendagri, dalam Arjuna Al Ichsan 13 Februari 2012).

Memperhatikan isi ketentuan Peraturan Menteri Dalam Negeri Nomor 76 Tahun 2012 tentang Tim Penegasan Batas Daerah (TPBD), terutama pada Pasal 18 sampai dengan Pasal 24, terlihat bahwa TPBD tingkat pusat, provinsi maupun kabupaten/kota, memiliki tugas yang cukup berat. Tri Ratnawati (2014) seorang peneliti dan pengamat sosial politik berpandangan, bahwa cara kerja TPBD yang sekilas teknis-matematis-mekanistis semata, pada kenyataannya, hasil kerja dan rekomendasirekomendasi mereka dapat berdampak sosial politik, ekonomi dan budaya yang sangat serius terhadap daerah. $^{3}$

Tri Ratnawati mengingatkan, hendaknya TPBD memiliki sikap kritis untuk tidak sekedar menjadi "tukang" yang bergembira ria karena banyaknya "order" atau "proyek" untuk menentukan batas-batas daerah pemekaran baru yang jumlahnya tampaknya akan terus berkembang. Saat ini saja diperkirakan telah ada sekitar 181 proposal pemekaran dari daerahdaerah yang telah masuk ke Kementerian Dalam Negeri, DPR-RI dan DPD-RI. Padahal, dari tahun 1999 hingga 2009, telah terbentuk 205 daerah pemekaran baru, ditambah sejumlah daerah pemekaran baru yang dibentuk sesudah tahun $2009 .^{4}$ Hingga bulan Maret 2014 ini, Indonesia telah

\footnotetext{
3 Disampaikan/dikutip dari Tri Ratnawati dalam Sidang TPM II di Badan Litbang Kemendagri Jakarta tanggal 15 April 2014.

4 Ibid.
} 
memiliki 539 daerah otonom, yakni 34 provinsi, 93 kota dan 412 kabupaten.

Data mengenai rendahnya kinerja TPBD tingkat pusat, dapat diketahui antara lain dari salah satu media cetak lokal yang menulis berikut ini: "Soal tapal batas ini memang menjadi masalah pelik. Setidaknya, sejak dibuka kran pemekaran daerah, hingga saat ini tercatat ada 946 konflik sengketa perbatasan, baik antarkabupaten/kota dalam satu provinsi, maupun kabupaten/kota dalam satu provinsi dengan kabupaten/kota di provinsi tetangga. Dari jumlah sebanyak 131 segmen batas telah terselesaikan, dengan telah dikeluarkannya Permendagri yang menetapkan batas. Sedang yang masih dalam proses penyelesaian, sebanyak 206. "Yang belum dilakukan penegasan sebanyak 609 segmen atau sekitar 64 persen. Ini yang sama sekali belum tersentuh", ujar Eko Subowo Direktur Wilayah Administrasi dan Perbatasan, Direktorat Jendral Pemerintahan Umum. Ditargetkan, pada 2012 bisa terselesaikan lagi 50 segmen batas wilayah yang disengketakan, dan hingga 2014, ditargetkan semua sudah beres". 5

Menurut Tri Ratnawati (2014), keberhasilan TPBD antara lain dapat diukur dari tingkat penerimaan hasil kerja mereka oleh pihak-pihak yang bersengketa dan berhentinya konflik. Akan tetapi, mencermati data yang ditampilkan dalam kutipan tersebut, maka dapat disimpulkan bahwa TPBD tingkat pusat kurang berhasil menjalankan tugas-tugasnya. Kekurangberhasilan tersebut, menurut Tri Ratnawati, antara lain disebabkan oleh faktor-faktor sebagai berikut: ${ }^{6}$

1. Tim lebih menonjolkan unsur-unsur teknismekanistis ketimbang unsur-unsur historissosiologis-politis-ekonomis dari batas-batas suatu daerah (daerah-daerah);

2. Kegagalan Pemerintah Pusat membendung aspirasi pemekaran dari daerah-daerah atau meningkatnya konflik-konflik perbatasan akibat menguatnya sentimen-sentimen primordial (kesukuan, kedaerahan dan keagamaan), telah menyebabkan TPBD kewalahan dan akhirnya tidak performed.

Selanjutnya Tri Ratnawati menekankan, agar Pemerintah Pusat dan para penyelenggara negara (termasuk di dalamnya TPBD), menyadari, bahwa making new boundaries (membuat perbatasanperbatasan baru) itu haruslah sangat hati-hati dan seobyektif mungkin. Hal ini mengingat makna perbatasan (boundary) tersebut bukan hanya batas fisik wilayah saja, tetapi juga menyangkut "batas-batas" non fisik (seperti etnisitas, bahasa, agama, serta adat istiadat/budaya) dan sumber daya alam (SDA). Pemekaran daerah bukanlah semata-mata terkait segregasi spasial belaka, tetapi sekaligus dapat menjadi proses segregasi budaya, sosial ekonomi dan politik,

\footnotetext{
5 “Tim Kemendagri Takut Dibacok”, 11 Februari 2012, http://sumutpos.co/2012/02/26367/tim-kemendagritakut-dibacok, Penentuan Tapal Batas Sumut-Riau tanpa Data Lapangan

6 Paper Tri Ratnawati ibid.
}

yang rawan konflik dan penyalahgunaan kekuasaan. Tanpa adanya sensitivitas dan antisipasi serta preventifikasi dari para penyelenggara pemerintahan dan para politisi terhadap dampak-dampak negatif pemekaran daerah, maka Indonesia diprediksi akan menghadapi "bom waktu" dari maraknya pemekaran daerah era reformasi. $^{7}$

Penyelesaian masalah batas-batas daerah, menurut Ratnawati, "ending-nya" tidak selalu sematamata dapat diselesaikan dengan proses-proses teknismekanistis kartometris karena bisa saja setelah metode kartometris mengeluarkan hasilnya, selanjutnya akan terjadi tawar-menawar antara para pihak yang berselisih sehingga mendapatkan keputusan politis yang dapat bersama-sama mereka terima (win-win solutions). Oleh karena itu Ratnawati berpendapat, bahwa TPBD perlu juga memperdalam pengetahuan serta kompetensi dan sensitivitas mereka di bidang budaya/adat-istiadat daerah, sosial politik dan ekonomi. Tim tersebut menurut Tri Ratnawati juga perlu ditambah anggotanya dari kalangan pakar ilmu-ilmu sosial politik, budaya, ekonomi dan lingkungan/ ekologi.

Selanjutnya Pemerintah menurut peneliti tersebut, perlu segera "mengerem" pemekaran daerah dan sekaligus bertanggung jawab untuk ikut membenahi daerah-daerah pemekaran yang kurang berkinerja baik yang jumlahnya saat ini diperkirakan sekitar 80 persen dari total daerah pemekaran yang dibentuk sejak tahun $1999 .^{8}$

Perlu dicatat, beberapa ketentuan pokok Peraturan Menteri Dalam Negeri Nomor 76 Tahun 2012 antara lain:

1. Tim penegasan batas daerah antara lain: pasal 18, 19, 20, dan 21

2. Tata Kerja Penegasan Batas antara lain: pasal 22, 23, dan 24

3. Penyelesaian perselisihan batas daerah antara lain oleh Gubernur pada: pasal 26, 27, 28, 29, 30, 31, dan 32

4. Penyelesaian Perselisihan oleh Menteri, antara lain pada: pasal 33, 34, 35, 36, 37, dan 38

5. Pendanaan pada Pasal 39

6. Pembinaan dan Pengawasan pada Pasal 40, yang dilakukan oleh Menteri, Gubernur dan Bupati/Walikota.

Berdasarkan paparan di muka, maka aspek regulasi, sumber daya manusia (SDM), dukungan anggaran serta peralatan, dan koordinasi, akan tim teliti untuk kemudian menyimpulkan efektif/tidaknya kinerja TPBD serta bagaimana pengaruhnya terhadap percepatan penyelesaian masalah sengketa batas daerah.

Penelitian ini mengambil lokasi penelitian di Provinsi Lampung dan Provinsi Kalimantan Timur

\footnotetext{
7 Tri Ratnawati, ibid.

8 Baca: Laporan Hasil Evaluasi Daerah Otonom Hasil Pemekaran (EDOHP). Jakarta: Ditjen Otonomi Daerah Kemendagri bekerjasama dengan Decentralization Support Facility, 2011.
} 
berdasar teknik purposive sampling (pengambilan sampel secara bertujuan. Provinsi Lampung dipilih karena merupakan salah satu provinsi di Indonesia yang rawan konflik, sedangkan Provinsi Kalimantan Timur dipilih karena provinsi tersebut kaya sumber daya alam (SDA). Di samping itu, pemilihan keduanya adalah karena disesuaikan dengan dana yang tersedia yang relatif terbatas.

Dari kedua provinsi inilah yang akan dicari permasalahan-permasalahan apa saja yang dihadapi TPBD di lapangan serta akan dicarikan solusi penyelesaiannya. Dari hasil penelitian lapangan diharapkan tim peneliti mampu dan dapat mengambil kesimpulan awal terhadap TPBD pada kedua provinsi tersebut. Informasi dan data yang Tim dapatkan dari para anggota TPBD, kemudian akan kami "cross check" (cek silang) dengan data-data dari masyarakat dan lain-lain.

Rumusan masalah pada penelitian ini adalah sebagai berikut:

1. Bagaimana TPBD dalam mengimplementasikan Permendagri Nomor 76 Tahun 2012 di daerah (khususnya Provinsi Lampung dan Kalimantan Timur)?

2. Bagaimana TPBD yang telah terbentuk di daerah (Provinsi Lampung dan Kalimantan Timur) dapat melaksanakan peran dan tugas fungsinya secara optimal?

Maksud dilakukannya penelitian ini adalah untuk mengkaji peran dan fungsi TPBD yang dilaksanakan oleh pemerintah dan pemerintah daerah berdasarkan Peraturan Menteri Dalam Negeri Nomor 76 tahun 2012. Sedangkan yang menjadi tujuan pelaksanaan penelitian antara lain: a) Mendalami implementasi TPBD dalam penegasan batas daerah di tingkat provinsi maupun kabupaten/kota, khususnya di Provinsi Lampung dan Kalimantan Timur, dan b) Tersusunnya rekomendasi yang aplikatif dalam rangka percepatan penegasan batas daerah. Sasaran dilakukannya penelitian adalah teridentifikasinya permasalahan yang dihadapi oleh TPBD dalam penyelesaian sengketa batas daerah di tingkat provinsi (khususnya provinsi Lampung dan Kalimantan Timur) dan kabupaten/kota serta diketahuinya kendala dan faktor-faktor penyebabnya sehingga dapat memberikan rekomendasi dalam rangka penguatan TPBD dan percepatan penegasan batas daerah.

\section{Teori “Boundary Making”}

Pada tahun 1945 seorang ahli geografi politik Amerika Serikat Sthepen B Jones dalam bukunya berjudul Boundary-making, merumuskan sebuah teori tentang sejarah adanya batas wilayah suatu negara dibagi dalam empat tahap utama, proses adanya batas wilayah suatu negara yaitu:

1. Keputusan politik untuk mengalokasi wilayah territorial (Allocation);

2. Delimitasi batas wilayah di dalam perjanjian (Delimitation);
3. Demarkasi batas wilayah di lapangan (Demarcation); dan

4. Mengadministrasikan batas wilayah (Administration).

Dalam konteks batas wilayah daerah otonom di Indonesia baik batas provinsi maupun batas daerah kabupaten/kota menurut Sutisna (2010) proses keberadaan batas daerah otonomi pada era otonomi daerah antara lain:

1. Alokasi wilayah adalah sebuah keputusan politik yang dalam praktiknya dituangkan dalam suatu keputusan yang mengikat dan konstitusional. Dalam praktik otonomi daerah di Indonesia alokasi disebut dengan istilah cakupan wilayah. Dalam hal alokasi wilayah daerah otonom, keputusan politik tertuang dalam konstitusi. Undang-Undang Dasar 1945 pasal 18 ayat 1 yang berbunyi Negara Kesatuan Republik Indonesia dibagi atas daerah-daerah provinsi dan daerah provinsi itu dibagi atas kabupaten dan kota yang mempunyai pemerintahan daerah yang diatur dengan undang-undang. Dalam praktiknya alokasi ini untuk wilayah darat, sedangkan alokasi di wilayah laut dituangkan dalam berbagai undang-undang pembentukan daerah.

2. Penetapan adalah sebuah keputusan hukum dan bagian dari administrasi publik, sehingga hal ini merupakan “domain" Pemerintah Pusat.

3. Penegasan batas daerah dititikberatkan pada upaya mewujudkan batas daerah yang jelas dan pasti baik dari aspek yuridis maupun fisik di lapangan. Penegasan batas daerah dilakukan dalam rangka menentukan letak dan posisi batas secara pasti di lapangan sampai penentuan titik koordinat batas di atas peta. Penegasan batas daerah berpedoman pada batas-batas daerah yang ditetapkan dalam undang-undang pembentukan daerah (Peraturan Menteri Dalam Negeri Nomor 1 Tahun 2006, yang kemudian diganti dengan Peraturan Menteri Dalam Negeri Nomor 76 Tahun 2012).

4. Proses panjang penentuan batas daerah yang dimulai dari negosiasi oleh para arsitek batas (the boundary architecs), dilanjutkan dengan delimitasi dan pengesahan undang-undang pembentukan daerah kemudian dilakukan tahap demarkasi oleh "the boundary engineers" dan akan diakhiri dengan tahap administrasi dan manajemen batas dan daerah perbatasan oleh masing-masing pemerintah daerah yang berbatasan. Proses panjang tersebut merupakan kulminasi dari proses politik, hukum dan teknis dan merupakan proses awal pengelolaan daerah perbatasan. Hal ini bertujuan untuk mempermudah koordinasi dan kerjasama pelaksanaan pembangunan maupun pembinaan kehidupan dan pelayanan kepada masyarakat, khususnya di daerah perbatasan. Implementasi dalam sistem otonomi daerah antara lain adalah 
menjadikan batas daerahdibuatkan produk hukum peraturan perundangan daerah (Perda).

Salah satu sumber lain menyatakan bahwa: "Memilih letak titik dan garis batas biasanya merupakan kompromi antara pertimbangan geografis dan kepentingan politik. Tahap memilih letak ini biasanya merupakan fase yang sangat kritis untuk mencapai kesepakatan letak titik dan garis batas. Sedangkan mendefinisikan garis batas merupakan suatu proses yang sebagian besar bersifat teknis (kartometris). Proses ini terdiri atas penentuan posisi (koordinat) titik-titik batas secara teliti dan kemudian mendefinisikannya yaitu menarik garis yang menghubungkan titik-titik batas tersebut di atas peta serta menguraikannya dalam bentuk narasi di dalam perjanjian (Jones, 1945). Karena kegiatan boundary making pada dasarnya kegiatan yang memiliki 3 aspek, yaitu: aspek politik, hukum, dan aspek teknis survey pemetaan, maka pada setiap tahapan diperlukan adanya suatu berita acara yang mencatat semua hasil kesepakatan yang disepakati pada tiap tahapan". 9

\section{Teori Dekonsentrasi dan Tugas Pembantuan}

Sebagaimana telah disebutkan dalam bagian sebelumnya, penyelesaian tapal batas ataupun segmen batas daerah selama ini merupakan kewenangan Pemerintah Pusat. Maka sangat beralasan bila Pemerintah Pusat dengan azas dekonsentrasi dan tugas pembantuan, membentuk Tim Penegas Batas Daerah Provinsi dan Tim Penegas Batas Daerah Kabupaten/Kota.

Oleh karena merupakan wewenang Pemerintah Pusat, maka implikasinya adalah Pemerintah Pusat memberikan pendanaan kepada pihak-pihak yang menerima wewenang dekonsentrasi dan tugas pembantuan tersebut. Di samping itu, Pemerintah Pusat juga seharusnya memberikan perbantuan tenaga ahli dan peralatan yang memadai kepada Provinsi dan Kabupaten/Kota sehingga tujuan untuk mempercepat penegasan batas daerah secara efektif, efisien dan dapat diterima para pihak, dapat tercapai.

Menurut Peraturan Pemerintah Nomor 7 Tahun 2008 tentang Dekonsentrasi dan Tugas Pembantuan, yang dimaksud dengan dekonsentrasi adalah "pelimpahan wewenang dari Pemerintah kepada gubernur sebagai wakil Pemerintah dan/atau kepada Instansi Vertikal di wilayah tertentu". ${ }^{10}$

9 www.scribd.com/doc/213728001/Metode-KartometrikSolusi-Tepat-Bagi-Penyelesaian-Perselisihan-BatasDaerah

10 PP No. 7 Tahun 2008 tentang Dekonsentrasi dan Tugas Pembantuan. Referensi mengenai dekonsentrasi, baca antara lain: Tri Ratnawati, "Otonomi Daerah Era Reformasi dan Urgensi Dekonsentrasi Parsial Dalam Negara Kesatuan Republik Indonesia Yang Demokratis", orasi pengukuhan profesor riset bidang Ilmu Politik, Lembaga Ilmu Pengetahuan Indonesia, Jakarta, Oktober 2011. Manor, James, 1999. The Political Economy of Democratic Decentralization.
Sedangkan Tugas Pembantuan adalah "penugasan dari Pemerintah kepada daerah dan/atau desa, dari pemerintah provinsi kepada kabupaten, atau kota dan/atau desa, serta dari pemerintah kabupaten, atau kota kepada desa untuk melaksanakan tugas tertentu dengan kewajiban melaporkan dan mempertanggungjawabkan pelaksanaannya kepada yang menugaskan". 11

Bersumber dari Tri Ratnawati (2011) ${ }^{12}$ yang mengutip pendapat Mark Turner dan David Hulme (1987), bahwa semua sistem pemerintahan mempraktikkan kombinasi sentralisasi dan desentralisasi kekuasaan. Hanya saja, bagaimana memadukan kombinasi yang tepat antara kontrol pusat dan otonomi daerah yang memuaskan rezim yang berkuasa di satu pihak, dan tuntutan masyarakat di lain pihak, merupakan dilema abadi bagi semua pemerintahan.

Selain itu, sentralisasi dan desentralisasi juga bukan merupakan atribut-atribut yang bisa didikotomikan karena keduanya berada dalam satu continuum yang sama dengan indikator yang berbedabeda ("All systems of government involve a combination of centralized and decentralized authority. However, finding a combination of central control and local autonomy that satisfies regime needs and popular demands is a persistent dilemma for governments. Centralization and decentralization are not attributes that can be dichotomized: rather they represent hypothetical poles on a continuum that can be calibrated by many different indices"(Hulme, Turner, 1997:159).

Merujuk pada argumen tersebut maka untuk menghapus sama sekali dekonsentrasi ("sentralisasi lunak") dalam penyelenggaraan pemerintahan, adalah sangat sulit. Bahkan, di negara federal yang demokratis sekali pun, di mana kekuasaan negaranegara bagian cukup besar, wewenang pertahanan negara dipegang secara terpusat oleh pemerintah federal (Ikrar Nusa Bhakti, Irine H.Gayatri (ed.), 2001).

Di samping kurang memiliki landasan teori yang kuat, bila ditinjau dari sejarah perkembangan pemerintahan daerah di Indonesia, maka tindakan/upaya pihak-pihak tertentu untuk menghapus dekonsentrasi dalam penyelenggaraan pemerintahan lokal, adalah merupakan tindakan yang ahistoris. Hal

The World Bank, Washington DC. Turner. Mac, David Hulme, 1987. Governance, Administration and Development, Making the State Work. London: McMillan Press. Ltd. Smith, B.C. 1985. The Territorial Dimension of The State. London: George Allen and Unwin.

11 PP No. 7 Tahun 2008

12 Tri Ratnawati, "Otonomi Daerah Era Reformasi dan Urgensi Dekonsentrasi Parsial Dalam Negara Kesatuan Republik Indonesia Yang Demokratis", orasi pengukuhan profesor riset bidang Ilmu Politik, Lembaga Ilmu Pengetahuan Indonesia, Jakarta, Oktober 2011.

Evaluasi Tim Penegasan Batas Daerah

(Studi Kasus di Provinsi Lampung dan Provinsi Kalimantan Timur) - 
itu karena dalam praktik penyelenggaraan pemerintahan daerah di negara kita, desentralisasi dan dekonsentrasi senantiasa dianut sekaligus dan dipraktikkan secara bersama-sama (The Liang Gie, jilid I, 1967:45).

Memang, ditinjau dari sudut pandang demokrasi, desentralisasi politik lebih "dekat" dengan demokrasi. Namun, desentralisasi politik memiliki kelemahan, yang mana kelemahan tersebut salah satunya dapat diatasi oleh dekonsentrasi atau desentralisasi administrasi. Seperti disinggung di muka, dekonsentrasi dapat mengejar tujuan-tujuan efisiensi dan efektivitas, tetapi bukan partisipasi masyarakat (Turner dan Hulme,1987:161).

Mark Turner dan David Hulme menyebutkan, bahwa rata-rata negara berkembang melaksanakan dekonsentrasi atau "desentralisasi administrasi", atau "field administration", dalam penyelenggaraan pemerintahan lokal (Turner, Hulme, 1987:160).

Desentralisasi menurut B.C. Smith memiliki sejumlah sisi positif. Dari sisi politik, desentralisasi dapat memperkuat akuntabilitas, kecakapankecakapan politik, dan integrasi nasional. Dari sudut pandang ekonomi, desentralisasi dapat mengurangi biaya, meningkatkan produktivitas, dan lebih efektif dalam penggunaan sumber daya manusia. Desentralisasi mendekatkan pemerintah kepada masyarakat, memberikan pelayanan yang lebih baik kepada masyarakat, memperkenalkan nilai-nilai kebebasan, kesetaraan dan kesejahteraan, memberikan dasar-dasar untuk partisipasi warga dan kepemimpinan politik, dan menjaga nilai-nilai dasar kemanusiaan (B.C. Smith, 1985: 4-5).

Mendukung pendapat B.C. Smith tersebut, Jorge V.Tigno menyatakan, desentralisasi politik menggeser kekuasaan pengambilan keputusan, dari pusat, ke pemerintahan yang lebih rendah sehingga mendorong partisipasi warga (Jorge V.Tigno, 2003:253).

Meskipun cukup banyak sisi positifnya, menurut pendapat Bank Dunia, desentralisasi bukanlah 'obat mujarab' (panacea) untuk segala jenis "penyakit”. Bank Dunia mencatat, desentralisasi tidak efisien untuk pelayanan-pelayanan stándar, rutin dan berdasarkan jaringan. Desentralisasi dapat menyebabkan hilangnya economies of scale dan hilangnya kontrol pemerintah pusat atas sumbersumber keuangan yang terbatas.

Selain itu, lemahnya administrasi atau kapasitas teknis di tingkat lokal menyebabkan pelayanan publik kurang efektif dan efisien; tanggung jawab administrasi yang ditransfer ke pemerintahan yang lebih rendah mungkin tidak dibarengi dengan sumbersumber keuangan yang cukup; desentralisasi kadang menyebabkan koordinasi kebijakan-kebijakan nasional semakin kompleks dan memungkinkan fungsi-fungsi "dibajak" oleh elit-elit lokal.Selanjutnya, ketidakpercayaan antara sektorsektor publik dan privat mungkin memperlemah kerjasama di tingkat lokal (World Bank Report 2001/2002).

Berdasarkan uraian mengenai sisi-sisi positif dan negatif dari desentralisasi tersebut maka dekonsentrasi merupakan salah satu instrumen untuk dapat menutup celah-celah, kelemahan-kelemahan desentralisasi. Sementara itu, dekonsentrasi diyakini dapat meningkatkan efektivitas dan efisiensi seperti telah disebutkan sebelumnya.

Pengaturan dekonsentrasi dalam Konstitusi dan Undang-Undang tersendiri sangat penting, terutama untuk mencegah terjadinya penyalahgunaan wewenang oleh pejabat-pejabat Pusat. ${ }^{13}$

Menurut Muhadam Labolo, dekonsentrasi, seperti halnya desentralisasi, potensial dijadikan "lahan" korupsi bagi para "pemburu rente", khususnya di kalangan pejabat-pejabat Pemerintah Pusat (Muhadam Labolo, 2004). Turner dan Hulme menyatakan, dekonsentrasi sering bersifat politis sehingga harus diawasi publik. Dekonsentrasi kadang dibelokkan tujuannya oleh elit-elit Pemerintah Pusat untuk memberikan keuntungan-keuntungan tertentu kepada penguasa.

Pejabat-pejabat Pusat di daerah juga sering membawa "misi" dari atasan mereka untuk memelihara stabilitas politik dan menghambat kelompok-kelompok politik oposisi, di samping untuk mengawasi peraturan-peraturan daerah agar tidak menyimpang dari ketentuan-ketentuan Pemerintah. Selanjutnya, dekonsentrasi juga dapat disalahgunakan penguasa untuk memonitor loyalitas politik pejabatpejabat pusat di daerah dan loyalitas pihak-pihak lain (Turner dan Hulme, 1997:161).

13 Pada tahun 1970, RUU tentang dekonsentrasi pernah dirancang Pemerintah dan telah diajukan kepada DPRGR. Sebelumnya, yaitu tahun 1968, RUU hubungan pemerintah dengan pemerintahan di daerah dan RUU tentang daerah swatantra, juga telah diajukan pemerintah ke DPR-GR. Ketiga paket RUU tersebut disiapkan pemerintah saat itu untuk melaksanakan TAP No.XXI/MPRS/1966 yang antara lain menetapkan pemberian otonomi seluas-luasnya kepada daerah. TAP MPR ini juga menetapkan politik dekonsentrasi sebagai komplemen yang vital dari desentralisasi.

TAP MPRS tersebut setelah pemilu 1971 kemudian dicabut dengan TAP No.IV/MPR/1973 tentang Garisgaris Besar Haluan Negara. TAP No.IV/MPR/1973, menekankan sama pentingnya asas desentralisasi dengan dekonsentrasi. Ketentuan ini kemudian dilaksanakan oleh UU No.5 Tahun 1974 (tentang Pokok-pokok Pemerintahan di Daerah) yang memperkenalkan konsep otonomi daerah "yang nyata dan bertanggung jawab" (Sumber: Dr. M.Solly Lubis, S.H., Perkembangan Garis Politik dan PerundangUndangan Pemerintahan Daerah. Bandung: Penerbit Alumni, 1983, hal. 2, 40. Tentang dekonsentrasi, baca pula: Muhadam Labolo, "Dilema Penyelenggaraan Dekonsentrasi”, dalam Jurnal Pamong Praja, Edisi 12004, hal. 81-91. 
Untuk mencegah kemungkinan-kemungkinan buruk tersebut, maka dekonsentrasi harus dibatasi, bukan dekonsentrasi seluas-luasnya. Dekonsentrasi yang terbatas tersebut dinamakan "dekonsentrasi parsial". ${ }^{14}$

Eko Prasodjo dkk. menyatakan bahwa dekonsentrasi merupakan penghalusan dari sentralisasi di mana pemerintah pusat dan aparat pusat di daerah merupakan pemain inti $(2006: 8,9)$. Selanjutnya Eko Prasojo menjelaskan sebagai berikut: ${ }^{15}$..."Dalam integrated prefectoral system, sektor pemerintahan yang ada di pusat memiliki kewenangan pengawasan, baik yang bersifat administratif maupun teknis terhadap pejabat instansi vertikal di daerah. Sedangkan dalam unintegrated prefectoral system, sektor pemerintah yang ada di pusat hanya memiliki kewenangan pengawasan yang bersifat administratif saja, sedangkan persoalan teknis sepenuhnya menjadi kewenangan instansi vertikal di daerah. Meskipun demikian unintegrated prefectoral system memiliki konsekuensi berupaya melemahnya koordinasi dan meningkatnya inefisiensi (Eko Prasodjo, 2006:10).

\section{Landasan Normatif}

Dasar hukum atau regulasi terkait dengan Kajian Taktis Evaluasi Tim Kinerja Penegasan Batas Daerah di antaranya adalah sebagai berikut:

1. Undang-Undang Dasar Tahun 1945;

2. Undang-Undang Nomor 32 Tahun 2004 tentang Pemerintahan Daerah (Lembaran Negara Republik Indonesia Tahun 2004 Nomor 125, Tambahan Lembaran Negara Nomor 4437) sebagaimana telah diubah beberapa kali, terakhir dengan Undang-Undang Nomor 12 Tahun 2008 tentang Perubahan Kedua atas Undang-Undang Nomor 32 Tahun 2004 tentang Pemerintahan Daerah (Lembaran Negara Republik Indonesia Tahun 2008 Nomor 59, Tambahan Lembaran Negara Nomor 4844);

3. Undang-Undang Nomor 39 Tahun 2008 tentang Kementerian Negara (Lembaran Negara Republik Indonesia Tahun 2008 Nomor 166, Tambahan Lembaran Negara Republik Indonesia Nomor 4916);

4. Undang-Undang Nomor 4 Tahun 2011 tentang Informasi Geospasial (Lembaran Negara Republik Indonesia Tahun 2011 Nomor 49, Tambahan Lembaran Negara Republik Indonesia Nomor 5214);

5. Peraturan Pemerintah Nomor 38 Tahun 2007 Tentang Pembagian Urusan Pemerintahan antara Pemerintah, Pemerintah Daerah Provinsi dan Pemerintah Daerah Kabupaten/Kota (Lembaran Negara Republik Indonesia Tahun 2007 Nomor

\footnotetext{
${ }^{14}$ Tri Ratnawati, idem ditto.

${ }^{15}$ Eko Prasojo dkk., Desentralisasi dan Pemerintahan Daerah: Antara Model Demokrasi Lokal dan Efisiensi Struktural. Fisip UI Juni 2006.
}

82, Tambahan Lembaran Negara Republik Indonesia Nomor 4737);

6. Peraturan Pemerintah Nomor 78 Tahun 2007 Tentang Tata Cara Pembentukan, Penghapusan dan Penggabungan Daerah (Lembaran Negara Republik Indonesia Tahun 2007 Nomor 162, Tambahan Lembaran Negara Republik Indonesia Nomor 4791);

7. Peraturan Pemerintah Nomor 7 Tahun 2008 tentang Dekonsentrasi dan Tugas Pembantuan;

8. Peraturan Pemerintah Nomor 19 Tahun 2010 Tentang Tata Cara Pelaksanaan Tugas dan Wewenang serta Kedudukan Keuangan Gubernur Sebagai Wakil Pemerintah di Wilayah Provinsi (Lembaran Negara Republik Indonesia Tahun 2010 Nomor 25, Tambahan Lembaran Negara Republik Indonesia Nomor 5107) sebagaimana diubah dengan Peraturan Pemerintah Nomor 23 Tahun 2011 Tentang Perubahan Atas Peraturan Pemerintah Nomor 19 Tahun 2010 Tentang Tata Cara Pelaksanaan Tugas dan Wewenang serta Kedudukan Keuangan Gubernur Sebagai Wakil Pemerintah di Wilayah Provinsi (Lembaran Negara Republik Indonesia Tahun 2011 Nomor 44, Tambahan Lembaran Negara Republik Indonesia Nomor 5209;

9. Peraturan Menteri Dalam Negeri Nomor 76 Tahun 2012 tentang Pedoman Penegasan Batas Daerah.

\section{Pengertian-Pengertian}

Wilayah perbatasan memiliki arti yang sangat vital dengan strategis, baik itu dilihat dari sudut pandang perbatasan kabupaten/kota dalam satu provinsi atau perbatasan kabupaten/kota antarprovinsi. Hal itu karena menyangkut pertahanan dan keamanan suatu negara, ekonomi, sosial dan budaya. Untuk menciptakan tertib administrasi pemerintahan, memberikan kejelasan dan kepastian hukum terhadap batas wilayah suatu daerah. (Psl 2 ayat 1 Permendagri Nomor 76 Tahun 2012).

Segmen, berasal dari bahasa Inggris, artinya: bagian, golongan atau ruas, (Echals \& Shadily, 2005:511).

Batas daerah adalah pembatas wilayah administrasi pemerintahan antardaerah yang merupakan rangkaian titik-titik koordinat yang berada pada permukaan bumi dapat berupa tanda-tanda alam seperti igir/punggung gunung/ pegunungan (watershed), median sungai dan/atau unsur buatan di lapangan yang dituangkan dalam bentuk Peta, (Pasal 1 angka 3 Permendagri Nomor 76 Tahun 2012).

Bertitik tolak dari pengertian-pengertian yang dikemukakan di atas, maka pengertian Penyelesaian Segmen Batas Darat Daerah Kabupaten/Kota, adalah usaha atau perbuatan membereskan, menyelesaikan bagian atau ruas pembatas wilayah administrasi pemerintahan antardaerah kabupaten/kota dalam bentuk rangkaian titik koordinat yang berada pada permukaan bumi, tanda-tanda alam seperti igir 
gunung/punggung gunung (watershed), median, sungai dan/atau unsur buatan di lapangan yang dituangkan dalam bentuk Peta. Usaha atau perbuatan membereskan, menyelesaikan bagian atau ruas pembatas dimaksud, sesuai dengan aturan normatifnya sebagaimana ditegaskan dan dituangkan lebih jelas dalam Permendagri Nomor 76 Tahun 2012.

Dengan perkataan lain usaha atau perbuatan untuk menyelesaikan segmen batas darat daerah kabupaten/kota antarprovinsi dimaksud ditandai dengan:

1. Waktu atau target waktu penyelesaian;

2. Keakuratan (validitas) data yang mendukung penyelesaian; dan

3. Komitmen atau kemauan yang baik (good will) dari masing-masing pihak.

Hal ini tergambar/terlihat pada tersedianya unit kerja yang mempunyai fungsi dan tugas yang jelas, tersedianya anggaran dalam APBD. Ini semua dapat ditetapkan dalam suatu dokumen strategis.

\section{Studi-studi/kasus-kasus terdahulu yang terkait}

Studi terdahulu yang pernah dilakukan adalah penelitian yang menyangkut segmen batas laut yang dilakukan Tim Peneliti Puslitbang Pemerintahan Umum dan Kependudukan Badan Litbang Kemendagri tahun 2011, dengan judul: "Penelitian Penyelesaian Sengketa Batas Antar Kabupaten/Kota, dan Kabupaten/Kota di luar provinsi (Suatu Alternatif Solusi Penyelesaian Segmen Batas Laut Bermasalah antara Provinsi Kepulauan Bangka Belitung dengan Provinsi Kepulauan Riau)".

Ulasan pokok penelitian ini adalah tentang konflik yang ditimbulkan akibat adanya sengketa segmen batas laut bermasalah antara Provinsi Kepulauan Bangka Belitung dengan Kepulauan Riau. Dari penelitian ini diharapkan digali lebih dalam upaya-upaya optimal apa saja yang dapat dijadikan sebagai suatu usulan alternatif pemecahan sengketa batas tersebut, sehingga tidak mengganggu hubungan antardaerah dan menjaga keutuhan NKRI.

Penelitian ini berasumsi bahwa fungsi esensial penyelesaian sengketa batas antardaerah adalah dengan mengelola dan menyelesaikan konflik (kepentingan) di antara daerah yang bersengketa tersebut. Oleh karenanya, penelitian ini berusaha mengelaborasi lebih jauh bagaimana penyelesaian sengketa segmen batas laut antara kedua provinsi tersebut dilakukan oleh Pemerintah Pusat, sehingga ke dua daerah yang bersengketa dapat menerima Keputusan Pemerintah Pusat.

Kesimpulan dari penelitian ini adalah perebutan suatu pulau yang dipersengketakan kepemilikannya oleh daerah, hanya akan menghabiskan anggaran daerah yang cukup besar. Selain itu, juga menguras tenaga dan waktu Pemerintah, Pemerintah Provinsi dan Pemerintah Kabupaten/Kota. Perebutan Pulau Pekajang oleh dua provinsi tersebut sebenarnya tidak perlu berlarut-larut mengingat ke dua pulau itu masih berada di wilayah jurisdiksi Indonesia. Hal yang penting adalah Pemerintah, baik Pemerintah maupun Daerah, harus meningkatkan kesejahteraan masyarakat yang tinggal di pulau terpencil itu.

\section{METODE PENELITIAN}

\section{Lokasi dan Waktu Pelaksanaan Kajian}

Tulisan/artikel ini didasarkan atas kajian yang dilaksanakan pada dua provinsi, yaitu: di Provinsi Lampung dan Provinsi Kalimantan Timur. Pelaksanaan kajian taktis ini berlangsung selama kurang lebih 3 (tiga) bulan dimulai dari bulan Maret sampai dengan bulan Juni 2014.

\section{Macam/Sifat Kajian}

Kajian ini bersifat deskriptif dengan pendekatan kualitatif dan kuantitatif yang saling melengkapi. Secara purposive sampling, Provinsi Lampung dan Provinsi Kalimantan Timur dipilih sebagai lokasi dalam kajian ini. Provinsi Lampung dipilih karena merupakan salah satu daerah di Indonesia yang rawan konflik, sedangkan Provinsi Kalimantan Timur dipilih karena daerah tersebut merupakan salah satu daerah di Indonesia yang kaya Sumber Daya Alam (SDA).

Metode deskriptif tersebut dirancang untuk mengumpulkan informasi yang diperlukan dengan teknik survei yakni mengumpulkan data yang relatif terbatas (sampel survei) dari sejumlah kasus yang relatif besar jumlahnya, dan dengan cara wawancara mendalam/in-depth interview dengan disiapkan suatu pedoman wawancara mendalam (Sevilla 1993:76). Pendekatan yang digunakan dalam penelitian ini adalah pendekatan kualitatif dan kuantitatif, dengan konsentrasi utama pada pendekatan kualitatif. Kombinasi kedua pendekatan ini diharapkan dapat meningkatkan tingkat kesahihan dan tingkat konfidensinya. Salah satu cara untuk menggabungkan pendekatan kualitatif dan kuantitatif dalam penelitian kebijakan sosial, menurut Brannen (1999), adalah pemakaian hasil-hasil kualitatif untuk menjelaskan temuan-temuan kuantitatif. Jadi macam/sifat kajian tersebut akan melihat dan mengkaji pelaksanaan kegiatan dan program atas pelaksanaan penyelesaian segmen batas antardaerah yang dilakukan TPBD yang diatur secara normatif diatur dalam Peraturan Menteri Dalam Negeri Nomor 76 Tahun 2012 tentang Pedoman Penegasan Batas Daerah.

\section{Metode Pengumpulan Data}

Metode Pengumpulan Data dalam kajian ini dilakukan dengan studi kepustakaan, observasi lapangan, FGD dan wawancara melalui informan kunci (Ketua atau orang yang terkait langsung dengan TPBD). Pengumpulan data sekunder diarahkan untuk mempelajari bahan-bahan tertulis yang berhubungan dengan TPBD. Hal ini dapat dilakukan dengan melihat hasil-hasil penelitian sebelumnya yang terkait dengan TPBD. Data sekunder ini diperoleh atas 
kegiatan membaca semua keterangan yang ada hubungannya dengan kajian.

\section{Metode Pengolahan dan Analisis Data}

\section{Metode Pengolahan Data}

Metode Pengolahan Data dilakukan dengan mendeskripsikan dan interfolasi hasil wawancara melalui pendekatan secara induktif dengan mengumpulkan fenomena-fenomena yang terjadi dilapangan kemudian diolah dan disimpulkan sebagai gambaran umum pada lokasi kajian.

\section{Analisis Data}

Setelah data terkumpul melalui instrumen kajian, kemudian dianalisis menurut model Miles dan Huberman (dalam Sugiyono, 2008: 246-253) yaitu aktivitas dalam analisis data melalui tiga (3) tahap/langkah sebagai berikut: 1) Data reduction atau reduksi data yaitu merangkum, memilih hal-hal yang pokok dan fokus, penting saja, sehingga dapat menggambarkan yang lebih jelas tentang penyelesaian segmen batas; 2) Data display (penyiapan data) setelah data direduksi maka selanjutnya adalah penyajian (display) data dalam bentuk tabel, dengan demikian, data tersebut dapat tersusun dalam pola hubungan atau saling terkait, sehingga dapat membentuk pemahaman tentang Tim Penegasan Batas Daerah di dua daerah sampel kajian; 3) Conclusion drawing (verification). Langkah ketiga adalah penarikan kesimpulan dan verifikasi, penarikan kesimpulan ini harus didukung data dan bukti-bukti lain yang valid dan konsisten. Melalui penarikan kesimpulan ini diharapkan dapat menjawab rumusan permasalahan.

\section{HASIL DAN PEMBAHASAN}

\section{Provinsi Lampung}

\section{Umum}

Pada Provinsi Lampung terdapat masalah batas daerah, salah satu contohnya yaitu permasalahan batas antara Kabupaten Lampung Selatan dengan Kabupaten Lampung Timur. Hal ini disebabkan oleh beberapa faktor antara lain seperti keterbatasan sumber daya manusia yang profesional (tenaga ahli), sarana dan prasarana, tidak melibatkan satuan pemerintahan terendah (camat, lurah/kades, RT/RW), kurangnya koordinasi antara pemerintah daerah, serta kurangnya dukungan pimpinan (misalnya, dalam program kerja Pemerintah Provinsi Lampung bukanlah menjadi prioritas).

\section{Kelembagaan}

Tim Penegasan Batas Daerah provinsi maupun kabupaten/kota di Provinsi Lampung hampir seluruhnya sudah terbentuk. Hal ini bisa dilihat dari kinerja tim dalam melakukan mediasi penyelesaian masalah penegasan batas dan pembuatan peta.

Dalam pelaksanaan tugas di lapangan, Tim Penegasan Batas Daerah mengalami beberapa kendala/hambatan di antaranya keterbatasan anggaran dan keterbatasan tenaga ahli anggota TPBD (kurang kompeten).

\section{Sumber Daya Manusia (SDM)}

Tidak bisa dipungkiri bahwa sebaik apapun suatu organisasi, faktor manusia merupakan kunci keberhasilan sebuah organisasi sehingga dalam mewujudkan komposisi ideal Tim penegasan batas daerah diperlukan SDM yang berkompeten terkait penegasan batas daerah. Fakta di lapangan menyatakan bahwa Ketua TPBD lebih bersifat ex officio sehingga sedikit mengenyampingkan unsur profesionalitas dalam susunan keanggotaan tim.

Hasil temuan di lapangan dikeluhkan bahwa komposisi TPBD perlu dimasukan unsur kepala wilayah di tingkat kecamatan, kelurahan/desa, dusun sampai RT/RW dan dibutuhkan tim operasional karena keterbatasan waktu dan yang tidak memungkinkan kepala daerah atau kepala SKPD terkait untuk turun langsung ke lapangan.

\section{Manajemen}

Sudut pandang manajemen lebih menitikberatkan pada anggaran yaitu guna mendukung pelaksanaan kegiatan Tim Penegasan Batas daerah. Anggaran penegasan batas daerah sesuai dengan Permendagri Nomor 76 tahun 2012 yaitu pendanaan pelaksanaan kegiatan penegasan batas daerah bersumber dari Anggaran Pendapatan dan Belanja Negara, Anggaran Pendapatan dan Belanja Daerah Provinsi, Anggaran Pendapatan dan Belanja Daerah Kabupaten/Kota dan sumber-sumber lainnya.

Pendapatan yang sah dan tidak mengikat yang tersedia untuk kegiatan TPBD di Tingkat Kabupaten/Kota Provinsi Lampung Khususnya dalam Penyelesaian Segmen Penegasan Batas Daerah dan kurang efektifnya TPBD terkait dengan anggaran yang sangat minim.

\section{Provinsi Kalimantan Timur}

\section{Umum}

Pada Provinsi Kalimantan Timur terdapat permasalahan di beberapa segmen batas, seperti antara Kabupaten Kutai Timur dengan Kabupaten Berau. Hal ini terkait dengan rencana DOB Berau Pesisir Selatan. Juga pada sebagian batas antara Kabupaten Berau Kaltim dengan Kabupaten Bulungan Kalimantan Utara. Walaupun begitu, semangat untuk mencari solusi penyelesaian dan memang keharusan bahwa permasalahan batas daerah harus diupayakan untuk diselesaikan.

Langkah-langkah yang diperlukan untuk penyelesaian batas daerah melalui: a) membangun semangat persaudaraan, kebersamaan dan mengutamakan musyawarah dan mufakat dalam penyelesaian persoalan batas; b) menempatkan supremasi hukum dalam setiap penyelesaian permasalahan penegasan batas; c) kewenangan TPBD Provinsi untuk memutuskan kasus yang tidak dapat 
diselesaikan oleh Pemkab/Pemkot harus diperkuat dengan dukungan anggaran dan kemampuan teknis yang memadai sehingga mampu mempercepat proses penyelesaian kegiatan penataan batas.

\section{Sumber Daya Manusia (SDM)}

Kapasitas TPBD pada saat ini sudah cukup ideal karena berasal dari beberapa disiplin ilmu dan SKPD yang terkait dengan penegasan batas. Anggota TPBD provinsi/kabupaten/kota relatif cukup baik dan telah mempunyai SDM yang memadai terutama sudah mengenal GPS, GIS, dan terutama harus dapat membaca Peta. Yang perlu ditingkatkan, secara ideal keanggotaan TPBD Provinsi dan unsur Dinas teknis yang memang menguasai bidang hukum, perundangundangan, teknis survey pemetaan dan sosial kemasyarakatan. Sedangkan komposisi keanggotaan dari TPBD yang ada dirasakan sudah cukup mewakili dari beberapa kalangan tersebut.

\section{Manajemen}

Untuk kegiatan penegasan batas daerah selalu mendapatkan anggaran dari APBD dan khusus untuk dua tahun terakhir ini juga mendapatkan dana dari Anggaran Dekonsentrasi Ditjen Pemerintahan Umum Kementerian Dalam Negeri dan APBN perubahan. Akan tetapi disayangkan anggaran tersebut hanya untuk melaksanakan rapat-rapat koordinasi, antara lain rapat-rapat koordinasi/rapat kerja perbatasan dan rapat koordinasi. Anggaran untuk kegiatan penegasan batas daerah dirasakan sudah cukup memadai.

\section{Kelembagaan/Organisasi}

Hubungan koordinasi antara TPBD Provinsi dengan TPBD Kabupaten/Kota sampai saat ini sangat baik. Hal ini dikarenakan TPBD Kabupaten/Kota jika menghadapi permasalahan selalu melakukan koordinasi dengan TPBD Provinsi atau sebaliknya. Tidak adanya tumpang tindih kewenangan antarTPBD Provinsi dengan TPBD Kabupaten/Kota yang telah mengacu pada Peraturan Menteri Dalam Negeri Nomor76 Tahun 2012. TPBD Pusat memiliki kewenangan penuh untuk batas dan TPBD Provinsi memiliki kewenangan batas antarKabupaten/Kota.

Peran TPBD Kabupaten/Kota di Provinsi Kaltim tidak ada masalah sesuai dengan kewenangan masing-masing. Akan tetapi sebaiknya tidak perlu melibatkan masyarakat adat dalam penyelesaian penegasan batas. Tokoh adat dapat dilibatkan pada waktu awal TPBD dibentuk. Hal ini agar pelibatan pada waktu awal tim bekerja untuk mengurangi konflik yang akan terjadi nanti jika telah didapatkan segmen batas yang diinginkan kedua pihak.Jadi pelibatan tokoh adat tidak dimaksudkan untuk pekerjaan ketika tim teknis penegasan batas mulai bekerja. Hal ini dikarenakan memang pengetahuan mereka tentang batas tidak atau kurang mereka menguasai, dan akan berakibat mereka selalu bertahan pada prinsip masing-masing sehingga sulit untuk mendapatkan kesepakatan terkait penegasan batas.
TPBD sendiri seharusnya diisi dengan personel yang kompeten dan fokus dengan pekerjaannya, dan sebaiknya tidak ditunggangi oleh kepentingan kelompok-kelompok tertentu. Hal ini dimaksudkan agar personalia TPBD memang benar-benar profesional yang mencakup para ahli/pakar dari multidisiplin dan termasuk teknis pemetaan, terkait dengan penegasan batas. Hal ini mengingat bila kita cermati keanggotaan TPBD baik di tingkat Pusat, Provinsi maupun Kabupaten/Kota seperti disebutkan dalam Permendagri Nomor 76 Tahun 2012 terlihat secara ex officio hanya mencakup para Pejabat yang berada di birokrasi pemerintahan semata. Dan memang tidak disebutkan perlunya ditambah keanggotaan dari para ahli yang multi disiplin. Oleh karena itu, perlu dimungkinkan adanya revisi terhadap regulasi dimaksudkan dengan menambah keanggotaan dari berbagai pakar multi disiplin keilmuan.

Sedangkan khususnya pada TPBD Kabupaten/Kota yang tidak mau wilayahnya dikurangi atau mengalah untuk kesepakatan agar diputuskan penegasan batasnya oleh TPBD Provinsi dan TPBD Pusat. Pada masa depan, TPBD Kabupaten/Kota berkonsentrasi pada segmen batas Desa, Kelurahan dan Kecamatan, Apalagi dengan keluarnya UndangUndang Nomor 6 Tahun 2014, berkecenderungan munculnya desa-desa baru dan ini harus ditindaklanjuti dan antisipasi TPBD Kabupaten/Kota harus lebih tanggap. Jadi TPBD Kabupaten/Kota lebih konsentrasi pada internal wilayahnya saja, tanpa disibuki dengan urusan segmen batas yang bersinggungan dengan wilayah tetangganya. Terkait dengan urgensi pembentukan tim penegas batas daerah kabupaten/kota yang jika regulasi yang ada adalah mereka disebutkan sebagai para pihak yang berkonflik sehingga sulit untuk tidak saling membawa/mempertahankan kepentingan masingmasing. Jadi sebenarnya tim penegas batas daerah hanya ada di tingkat Pusat dan Provinsi saja. Hal ini perlu revisi Peraturan Menteri Dalam Negeri Nomor 76 Tahun 2012 terutama pada pasal yang menyebut sebagai para pihak digantikan sebagai saksi.

Sedangkan untuk urusan penanganan segmen batas Kabupaten/Kota ditangani oleh Pemerintah dan Pemerintah Provinsi. Hanya saja dalam hal ini Pemerintah perlu lebih mengoptimalkan kinerja TPBD baik di tingkat Pusat maupun di Daerah. Mengingat yang menetapkan dan menegaskan batas daerah adalah domain Pemerintah (state domain), maka tugas pembantuan untuk penegasan batas daerah kepada pihak Pemerintah Kabupaten/ Pemerintah Kota seyogyanya diberikan termasuk pembiayaan/dana dari Pusat/APBN. Hal ini termasuk bantuan tenaga ahli dan peralatan dari Pusat sebagaimana halnya yang diterima Gubernur sebagai alat Pusat menerima dana dekonsentrasi dari Anggaran Pendapatan dan Belanja Daerah (APBN). 


\section{SIMPULAN}

Pada Provinsi Lampung dan Kalimantan Timur masih terdapat masalah batas daerah, di Provinsi Lampung yaitu permasalahan batas antara Kabupaten Lampung Selatan dengan Kabupaten Lampung Timur sementara di Provinsi Kalimantan Timur yaitu Kabupaten Kutai Timur dengan Kabupaten Berau. Masalah umum yang dihadapi antara lain disebabkan oleh beberapa faktor seperti keterbatasan sumber daya manusia yang profesional (tenaga ahli), kurangnya koordinasi antara pemerintah daerah, sarana dan prasarana yang belum menjangkau sampai ke daerah pelosok, serta kurangnya dukungan pimpinan di mana dalam program kerja Penegasan Batas Daerah belum menjadi suatu hal yang prioritas.

Tim Penegasan Batas Daerah provinsi maupun kabupaten/kota di Provinsi Lampung maupun Kalimantan Timur hampir seluruhnya sudah terbentuk. Namun dari segi keanggotaan TPBD yaitu belum adanya tim operasional lapangan yang professional. Kenyataan di lapangan membuktikan bahwa Ketua TPBD lebih bersifat ex officio sehingga sedikit mengenyampingkan unsur profesionalitas dalam susunan keanggotaan tim.

Sudut pandang manajemen lebih menitikberatkan pada anggaran yaitu sesuai dengan Permendagri Nomor 76 tahun 2012 yaitu pendanaan pelaksanaan kegiatan penegasan batas daerah bersumber dari Anggaran Pendapatan dan Belanja Negara, Anggaran Pendapatan dan Belanja Daerah Provinsi, Anggaran Pendapatan dan Belanja Daerah Kabupaten/Kota dan lain-lain sumber. Kebanyakan dalam penyelesaian segmen Batas Daerah Kurang epektifnya TPBD diakibatkan karena anggaran yang sangat minim yakni perbandingan antara luas wilayah perbatasan dengan jumlah biaya tidak seimbang sehingga hal ini pula membatasi Tim untuk dapat menjangkau daerah-daerah yang sangat jauh dan terpencil. TPBD Provinsi harus mulai diperkuat melalui dukungan anggaran, kewenangan dan adanya kemampuan teknis yang memadai sehingga diharapkan mampu mempercepat proses penyelesaian kegiatan penataan batas.

\section{Rekomendasi}

Berdasarkan hasil dan pembahasan penelitian ini, disampaikan rekomendasi sebagai berikut: Pertama, perlunya merevisi Permendagri Nomor 76 Tahun 2012 khususnya yang menyangkut keanggotaan TPBD baik tingkat Pusat, Provinsi maupun Kabupaten/Kota tidak hanya tim secara $e x$ officio semata, tetapi harus didukung dengan keanggotaan yang professional. memiliki kewenangan untuk batas antarKabupaten /Kota.

Kedua, khusus untuk TPBD Kabupaten/Kota diarahkan pada penegasan segmen batas desa, kelurahan dan kecamatan. Hal ini jika dikaitkan dengan PP Nomor 38 Tahun 2007, pada pembagian urusan pemerintahan bidang otonomi daerah dan pemerintahan umum, administrasi keuangan daerah, perangkat daerah, kepegawaian dan persandian maka tugas Pemerintahan Kabupaten/Kota hanyalah sebagai penetapan kebijakan dan pelaksanaan perbatasan kecamatan dan desa/kelurahan di kabupaten/kota bersangkutan. Oleh karena itu, maka TPBD Kabupaten/Kota diarahkan seperti disebutkan pada regulasi lebih tinggi tersebut. Ketiga, penegasan segmen batas kabupaten/kota langsung ditetapkan oleh Mendagri atas usul masukan segmen batas kabupaten/kota dari Gubernur sebagai wakil Pemerintah di daerah.

\section{DAFTAR PUSTAKA}

M. Solly Lubis. 1983. Perkembangan Garis Politik dan Perundang-Undangan Pemerintahan Daerah. Bandung: Penerbit Alumni.

Manor, James. 1999. The Political Economy of Democratic Decentralization, The World Bank.

Muhadam Labolo. 2004."Dilema Penyelenggaraan Dekonsentrasi”. dalam Jurnal Pamong Praja, Edisi Kesatu

Smith, B.C. 1985. The Territorial Dimension of the State. London: George Allen and Unwin.

Tri Ratnawati. "Otonomi Daerah Era Reformasi dan Urgensi Dekonsentrasi Parsial Dalam Negara Kesatuan Republik Indonesia yang Demokratis", orasi pengukuhan professor riset bidang Ilmu Politik, Lembaga Ilmu Pengetahuan Indonesia, Jakarta, Oktober 2011.

Tuner Mac, David Hulme. 1987. Governance Administrative and Development, Making the Size Work. London: Mc.Millan Press Ltd.

Peraturan perundang-undangan:

Peraturan Menteri Dalam Negeri Nomor 76 Tahun 2012 tentang Pedoman Penegasan Batas Daerah.

Peraturan Pemerintah Nomor 19 Tahun 2010 tentang Tata Cara Pelaksanaan Tugas dan Wewenang serta Kedudukan Keuangan Gubernur Sebagai Wakil Pemerintah di Wilayah Provinsi (Lembaran Negara Republik Indonesia Tahun 2010 Nomor 25, Tambahan Lembaran Negara Republik Indonesia Nomor 5107) sebagaimana diubah dengan Peraturan Pemerintah Nomor 23 Tahun 2011 Tentang Perubahan Atas Peraturan Pemerintah Nomor 19 Tahun 2010 Tentang Tata Cara Pelaksanaan Tugas dan Wewenang serta Kedudukan Keuangan Gubernur Sebagai Wakil Pemerintah di Wilayah Provinsi (Lembaran Negara Republik Indonesia Tahun 2011 Nomor 44, Tambahan Lembaran Negara Republik Indonesia Nomor 5209.

Peraturan Pemerintah Nomor 38 Tahun 2007 tentang Pembagian Urusan Pemerintahan antara Pemerintah, Pemerintah Daerah Provinsi dan Pemerintah Daerah Kabupaten/Kota (Lembaran Negara Republik Indonesia Tahun 2007 Nomor 82, Tambahan Lembaran Negara Republik Indonesia Nomor 4737).

Peraturan Pemerintah Nomor 78 Tahun 2007 tentang Tata Cara Pembentukan, Penghapusan dan 
Penggabungan Daerah (Lembaran Negara Republik Indonesia Tahun 2007 Nomor 162, Tambahan Lembaran Negara Republik Indonesia Nomor 4791).

PP No. 7 Tahun 2008 tentang Dekonsentrasi dan Tugas Pembantuan.

Undang-Undang Nomor 32 Tahun 2004 tentang Pemerintahan Daerah (Lembaran Negara Republik Indonesia Tahun 2004 Nomor 125, Tambahan Lembaran Negara Nomor 4437) sebagaimana telah diubah beberapa kali, terakhir dengan Undang-Undang Nomor 12 Tahun 2008 tentang Perubahan Kedua atas Undang-Undang Nomor 32 Tahun 2004 tentang Pemerintahan Daerah (Lembaran Negara Republik Indonesia Tahun 2008 Nomor 59, Tambahan Lembaran Negara Nomor 4844).

Undang-Undang Nomor 39 Tahun 2008 tentang Kementerian Negara (Lembaran Negara Republik Indonesia Tahun 2008 Nomor 166, Tambahan Lembaran Negara Republik Indonesia Nomor 4916).

Undang-Undang Nomor 4 Tahun 2011 tentang Informasi Geospasial (Lembaran Negara Republik Indonesia Tahun 2011 Nomor 49, Tambahan Lembaran Negara Republik Indonesia Nomor 5214).

UUD 1945. 